\begin{tabular}{|c|c|c|c|}
\hline \multirow{2}{*}{$\begin{array}{r}\text { Case Reports in } \\
\text { Gastroenterology }\end{array}$} & \multicolumn{2}{|c|}{ Case Rep Gastroenterol 2017;11:225-228 } & \multirow[b]{2}{*}{$\begin{array}{l}\text { Karger } \\
\text { Open access }\end{array}$} \\
\hline & $\begin{array}{l}\text { DOI: } 10.1159 / 000468513 \\
\text { Published online: April 19, } 2017\end{array}$ & $\begin{array}{l}\text { (C) } 2017 \text { The Author(s) } \\
\text { Published by S. Karger AG, Basel } \\
\text { www.karger.com/crg }\end{array}$ & \\
\hline & $\begin{array}{l}\text { This article is licensed under } \\
\text { International License (CC BY- } \wedge \\
\text { Usage and distribution for comn }\end{array}$ & $\begin{array}{l}\text { mons Attribution-NonCommercial } \\
\text { rger.com/Services/OpenAccessLicense) } \\
\text { quires written permission. }\end{array}$ & \\
\hline
\end{tabular}

\title{
Cholecystoparietal Fistula Revealed by an Epigastric Abscess
}

\author{
Assamoi Brou Fulgence Kassi Eric Koffi Kacou Sébastien Yénon \\ Cynthia Bombet-Kouamé \\ Department of Digestive Surgery, Cocody University Hospital, Abidjan, Ivory Coast
}

\section{Keywords}

Cholecystocutaneous fistula - Gallbladder abscess - Acute cholecystitis · Ultrasound-guided aspiration · Cholecystectomy · Biliary fistula $\cdot$ Biliary injury

\begin{abstract}
Cholecystocutaneous fistula, the ultimate complication of abscessed or overlooked acute cholecystitis, is due to perforation of the gallbladder in the abdominal wall. The authors report an unusual case of cholecystoparietal fistula revealed by an epigastric abscess. Fistulography and modern imaging tools make the diagnosis easier. Surgery is the best available treatment.

(C) 2017 The Author(s)

Published by S. Karger AG, Basel
\end{abstract}

\section{Introduction}

Acute cholecystitis is a pathology of inflammatory origin, usually associated with cholelithiasis, which has a high incidence in developed countries [1]. It is caused by the obstruction of the cystic duct by gallstones, release of lysolecithin, and ascending bacterial infection of the biliary fluid [2]. At this stage, surgery alone is sufficient for treatment. Overlooked or untreated, it can develop complications such as abscess, perforation, and exceptionally cholecystocutaneous fistulas. Cholecystocutaneous fistula is an unusual complication caused by perforation of the gallbladder in the abdominal wall [3]. Fistulography and modern imaging tools make the diagnosis easier. Treatment relies on cholecystectomy, surgical drainage of 


\section{Case Reports in Gastroenterology}

Case Rep Gastroenterol 2017;11:225-228 DOI: $10.1159 / 000468513$ (c) 2017 The Author(s). Published by S. Karger AG, Basel www.karger.com/crg

Kassi et al.: Cholecystoparietal Fistula Revealed by an Epigastric Abscess

the parietal abscess, and broad-spectrum antibiotherapy. We report an unusual case of cholecystoparietal fistula revealed by an epigastric abscess.

\section{Case Presentation}

A 46-year-old patient, with a medical history of isolated and unexplored right upper quadrant and epigastric pain, presented with a painful, fluctuating, epigastric swelling of 15 days' duration. There was no fever. Clinical examination revealed a $11 \times 10 \mathrm{~cm}$ epigastric abscess and a steady, painful hepatomegaly. Abdominal ultrasonography and CT scan (Fig. 1) showed a $15 \times 12 \mathrm{~cm}$ left paramedian parietal collection.

Blood tests revealed WBC of $12,000 / \mathrm{mm}^{3}$ and inflammatory anemia of $9.8 \mathrm{~g} / \mathrm{dl}$. Ultrasound-guided aspiration yielded $250 \mathrm{~mL}$ of fetid pus, and a drain was inserted for irrigation. Gastroduodenal endoscopy showed a vast bulbar ulcer, and Helicobacter pylori was found to be present on pathological examination of the gastric biopsies. Ulcer treatment with $H$. pylori eradication was then initiated. However, because of an increase to $500 \mathrm{~mL} /$ day of parietal suppuration output, it was decided 1 week later to use a surgical drainage. An abscessed gallbladder containing multiple gallstones was found and had fistulated in the abdominal wall (Fig. 2). Cholecystectomy was done and a multitubulated drain was put in front of the vesicular bed and brought out on the right side. A biliary fistula occurred on the 5th postoperative day, discharging through the drain site. A reoperation was performed during which no biliary injury could be found. Peritoneal lavage and large subhepatic drainage were carried out.

\section{Discussion}

The distinctive characteristic of our clinical case is related to the pattern of the clinical revelation of the cholecystoparietal fistula and to the failure of the imaging examinations.

Spontaneous cholecystocutaneous fistula, the ultimate evolution of cholecystoparietal fistula, is a rare complication of acute, abscessed cholecystitis with or without lithiasis as origin; only 25 cases have been reported during the last 50 years [4, 5].

A lack of a history of biliary pain or a paucisymptomatic pattern is often reported in spontaneous cholecystocutaneous fistulas $[5,6]$. In our patient, there was an isolated and unspecific right upper quadrant and epigastric pain. The parietal abscess occurred quietly, without fever, which is in contrast with the cases usually reported [7]. The lack of clinical signs in the recent history, which could lead to a diagnosis of acute or chronic cholecystitis, and the epigastric site of the parietal abscess have resulted in our patient in the erroneous diagnosis of a simple cutaneous abscess. The site of the parietal abscess is not really specific in the case of cholecystocutaneous fistula. In fact, even if the upper quadrant of the abdomen has been the most frequently reported site [8], the fistulization of the abscessed gallbladder can show up on the umbilicus, on the right side or the right iliac fossa [9].

The diagnostic value of abdominal ultrasonography and CT scan has been mentioned by numerous authors $[10,11]$. However, in our patient, these examinations did not help, as already reported by other authors [12]. The increase of the abscess output despite a wellconducted ultrasonography-guided drainage led to the suspicion of an intraperitoneal origin. Finally, exploratory laparotomy made the definitive diagnosis possible. 
The biliary fistula which occurs in the postoperative course shows the difficulties of the surgical treatment of spontaneous cholecystocutaneous fistulas. Percutaneous biliary drainage is an alternative, mainly in high-risk patients [11].

\section{Conclusion}

In case of unspecific symptoms and a lack of a history of biliary pain, an epigastric abscess should lead to the suspicion of an abscessed gallbladder fistulized in the abdominal wall. Surgery is the best available treatment.

\section{Statement of Ethics}

There are no ethical conflicts to declare.

\section{Disclosure Statement}

The authors declare no conflicts of interest.

\section{References}

1 Sakorafas GH, Milingos D, Peros G: Asymptomatic cholelithiasis: is cholecystectomy really needed? A critical reappraisal 15 years after the introduction of laparoscopic cholecystectomy. Dig Dis Sci 2007;52:1313-1325.

2 Schuld J, Glanemann M: Acute cholecystitis. Viszeralmedizin 2015;31:163-165.

-3 Kapoor Y, Singh G, Khokhar M: Spontaneous cholecystocutaneous fistula - not an old time story. Indian J Surg 2013;75:188-191.

4 Vasanth A, Siddiqui A, O’Donnell K: Spontaneous cholecystocutaneous fistula. South Med J 2004;97:183-185.

5 Geraghty A, Kettlewell S, Arestis N: Cholecystocutaneous abscess: diagnostic difficulty in a groin lump. BMJ Case Rep DOI: 10.1136/bcr.03.2012.5997.

6 Mathonnet M, Maisonnette F, Gainant A, Cubertafond P: Fistule cholécysto-cutanée spontanée: histoire naturelle de la cholécystite lithiasique. Ann Chir 2002;127:378-380.

-7 Szijártó A, Lévay B, Kupcsulik P: Unusual consequences of "incomplete" laparoscopic cholecystectomy. Eur J Gastroenterol Hepatol 2014;26:357-360.

-8 Sodhi K, Athar M, Kumar V, Sharma ID, Husain N: Spontaneous cholecystocutaneous fistula complicating carcinoma of the gallbladder: a case report. Indian J Surg 2012;74:191-193.

-9 Yüceyar S, Ertürk S, Karabiçak I, Onur E, Aydogan F: Spontaneous cholecystocutaneous fistula presenting with an abscess containing multiple gallstones: a case report. Mt Sinai J Med 2005;72:402404.

10 Jayant M, Kaushik R, Attri AK: Spontaneous cholecystocutaneous abscess. Indian J Gastroenterol 2014;33:498.

11 Pezzilli R, Barakat B, Corinaldesi R, Cavazza M: Spontaneous cholecystocutaneous fistula. Case Rep Gastroenterol 2010;4:356-360.

12 Jayasinghe G, Adam J, Abdul-Aal Y: Unusual presentation of gallbladder perforation. Int J Surg Case Rep 2016;18:42-44 


\section{Case Reports in Gastroenterology}

\begin{tabular}{l|l}
\hline Case Rep Gastroenterol 2017;11:225-228 \\
\hline DOI: 10.1159/000468513 & $\begin{array}{l}\text { ○ 2017 The Author(s). Published by S. Karger AG, Basel } \\
\text { www.karger.com/crg }\end{array}$ \\
\hline
\end{tabular}

Kassi et al.: Cholecystoparietal Fistula Revealed by an Epigastric Abscess

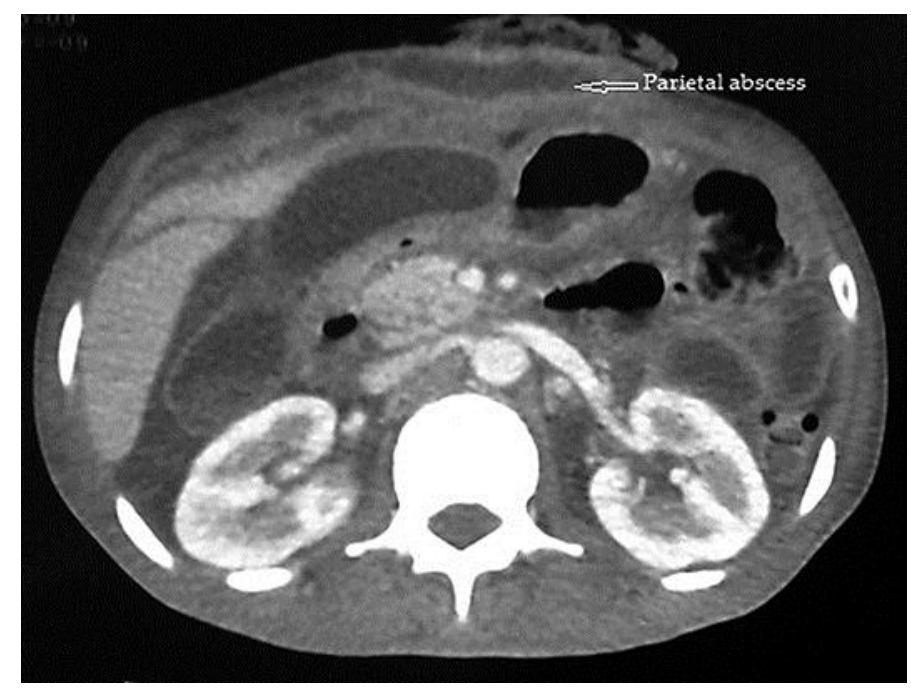

Fig. 1. Axial contrast-enhanced CT image showing parietal abscess (white arrow).

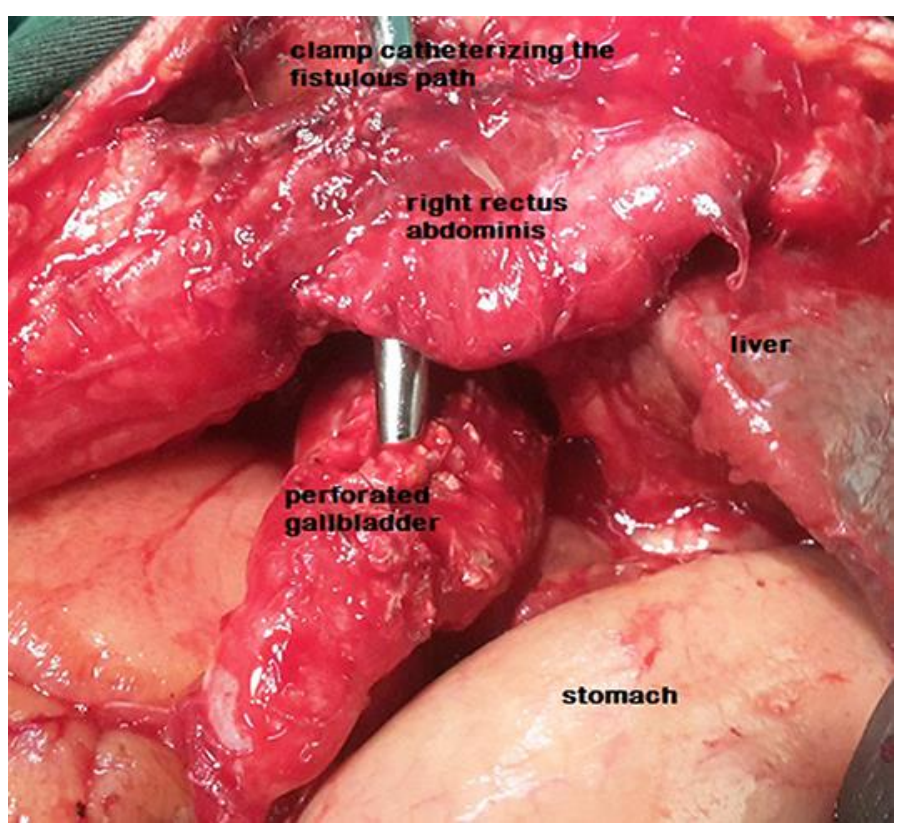

Fig. 2. Operative view. Clamp showing the path of the abscessed gallbladder fistula in the abdominal wall. 